OPEN ACCESS

Edited by:

Sergei Vatolin,

Case Western Reserve University,

United States

Reviewed by:

Sushree Sahoo,

St. Jude Children's Research Hospital,

United States

Alessandra Romano,

University of Catania, Italy

${ }^{*}$ Correspondence:

Fatih M. Uckun

fatih.uckun@att.net

Specialty section:

This article was submitted to Neoplastic Pathologies of Aging,

a section of the journal

Frontiers in Aging

Received: 11 August 2021 Accepted: 14 September 2021 Published: 27 September 2021

Citation:

Uckun FM and Watts J (2021) CD123Directed Bispecific Antibodies for

Targeting MDS Clones and

Immunosuppressive Myeloid-Derived Suppressor Cells (MDSC) in High-Risk

Adult MDS Patients.

Front. Aging 2:757276.

doi: 10.3389/fragi.2021.757276

\section{CD123-Directed Bispecific Antibodies for Targeting MDS Clones and Immunosuppressive Myeloid-Derived Suppressor Cells (MDSC) in High-Risk Adult MDS Patients}

\author{
Fatih M. Uckun ${ }^{1,2 *}$ and Justin Watts ${ }^{3}$ \\ ${ }^{1}$ Aptevo Therapeutics, Seattle, WA, United States, ${ }^{2}$ Immuno-Oncology Program, Ares Pharmaceuticals, St. Paul, MN, \\ United States, ${ }^{3}$ University of Miami Sylvester Comprehensive Cancer Center, Miami, FL, United States
}

There is an urgent need to identify effective strategies to prevent leukemic transformation and induce sustained deep remissions in adult high-risk myelodysplastic syndrome (MDS) patients. This article discusses the clinical impact potential of bispecific antibodies (BiAB) capable of redirecting host $\mathrm{T}$-cell cytotoxicity in an $\mathrm{MHC}$-independent manner to malignant clones as well as immunosuppressive myeloid-derived suppressor cells (MDSC) as a new class of anti-MDS drug candidates. T-cell engaging BiAB targeting the CD123 antigen may help delay disease progression in high-risk adult MDS and potentially reduce the risk of transformation to secondary AML.

Keywords: CD123, bispecific antibody, MDSC, MDS, T-cells, APVO436

\section{INTRODUCTION}

Adult myelodysplastic syndrome (MDS), a heterogeneous group of clonal malignant hematologic disorders with an incidence rate of 4.5 per 100,000 persons per year, is characterized by ineffective hematopoiesis, abnormal differentiation of progenitor cells in the myeloid, erythroid, and megakaryocytic compartments, emergence of dysplastic myeloid cells, and an enhanced risk of transformation to acute myeloid leukemia (AML) (National Cancer Institute, 2016; National Cancer Institute, 2021; Zhan and Park, 2021). There is no effective standard treatment that will prevent the leukemic transformation or result in sustained deep remissions in high-risk adult MDS patients (Garcia-Manero, 2014; Götze and Platzbecker, 2018; Syed et al., 2020; Platzbecker et al., 2021). Several new therapies are being evaluated in clinical trials for their clinical impact potential for highrisk adult MDS patients, including new generation HMAs, isocitrate dehydrogenase inhibitors, the Hedgehog pathway inhibitor glasdegib, venetoclax plus azacitidine, CPX-351, the anti-CD47 monoclonal antibody magrolimab and the NEDD8 inhibitor pevonedistat, both in combination with azacitidine, and kinase inhibitors such as rigosertib, midostaurin, gilteritinib, and bemcentinib (Garcia-Manero, 2014; Götze and Platzbecker, 2018; Syed et al., 2020; Platzbecker et al., 2021; Sekeres et al., 2021).

The immunosuppressive bone marrow microenvironment (BMME) in adult MDS has been implicated in clonal evolution and disease progression (Sallman and List, 2019; Younos et al., 2015; Chen et al., 2013; Gañán-Gómez et al., 2015). Expanded populations of myeloid-derived suppressor cells (MDSC), representing $\mathrm{CD} 33^{+} \mathrm{CD} 123^{+}$immature myeloid cells within the bone marrow mononuclear cell fraction contribute to the immunosuppressive tumor microenvironment 


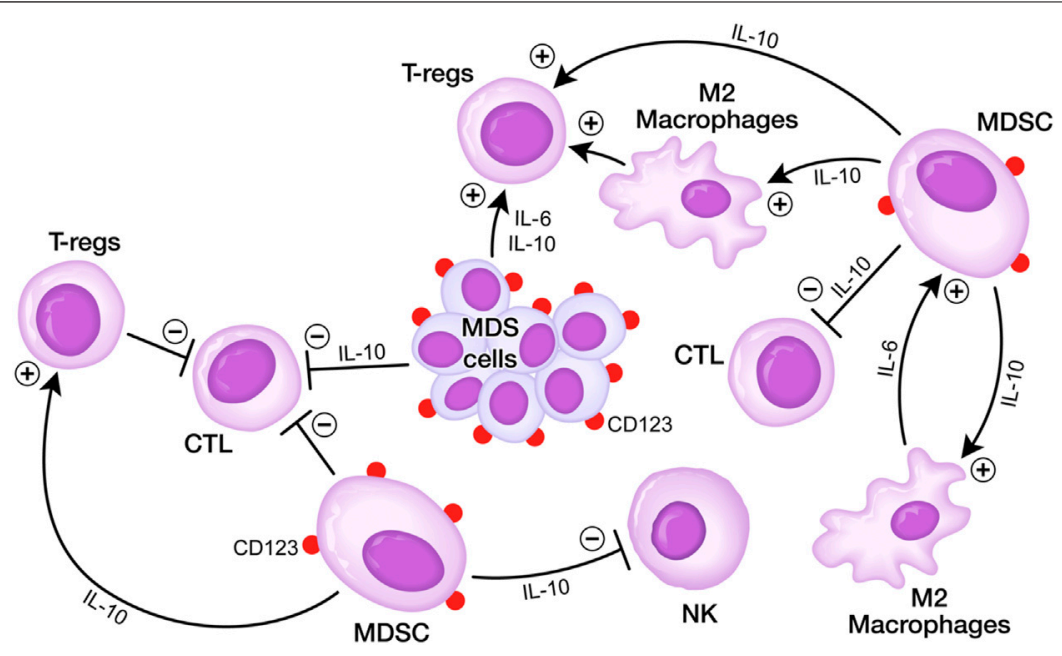

FIGURE 1 | Immunosuppressive BMME in MDS. (A) MDS cells secrete several cytokines including IL-6 and IL10 that inhibit DCs, CTLs, but stimulate Tregs. MDSCs are stimulated via IL-6 by M2 macrophages and stimulate M2 macrophages as well as Tregs via IL10, but they inhibit via IL10 CTLs and NK cells. MDSCs express CD123 antigen on their surface which can be targeted by T-cell redirecting bispecific antibodies. See text for detailed discussion.

(TME) by inhibiting both memory and cytotoxic effector T-cell populations as well as natural killer (NK) cells, thereby promoting the immune evasion of MDS clones (Sallman and List, 2019; Younos et al., 2015; Chen et al., 2013; Gañán-Gómez et al., 2015; Parker et al., 2015; Movahedi et al., 2008; Marvel and Gabrilovich, 2015) (Figure 1). The abundance of MDSC is associated with a higher risk of rapidly progressive disease and poor survival outcomes in adult MDS (Chen et al., 2013; Younos et al., 2015; Sallman and List, 2019).

The $\alpha$-chain of the IL-3 receptor, also known as the CD123 antigen, is broadly expressed on the bulk population of malignant MDS clones as well as leukemic blast and malignant hematopoietic stem and progenitor cells from AML patients (Jordan et al., 2000; Testa et al., 2002; Jin et al., 2009; Vergez et al., 2011; Hwang et al., 2012; Li et al., 2014; Testa et al., 2014; Chen et al., 2019). Furthermore, matched-pair analysis of samples from adult MDS patients who developed secondary AML with multi-parameter fluorescence-activated cell sorting and functional assays demonstrated that CD123 antigen is present on pre-malignant and malignant stem cells and blast cells in adult MDS (Chen et al., 2019). The expression of CD123 on MDSC as well as MDS clones provides a compelling rationale for targeting CD123 antigen on the malignant clones as well as the MDSC in the immunosuppressive BMME of adult MDS patients in an effort to delay disease progression and transformation to AML. Several biotherapeutic agents targeting CD123 have been developed and clinically evaluated in patients with AML and MDS, including the CD123-directed recombinant human IL3 fusion toxin Tagraxofusb (SL-401), monoclonal antibodies, bispecific antibodies targeting CD123 antigen, such as bispecific T-cell engagers, dual affinity retargeting antibodies, bispecific killer cell engagers, and tri-specific killer cell engagers (AL Hussaini et al., 2013; Kovtun et al., 2018; Comeau et al., 2019; Aldoss et al., 2020; Bai et al., 2020; Uy et al., 2021a; Daver et al., 2021; Isidori et al., 2021; Tabata et al.,
2021). Antibody-drug conjugates (ADC) are linked to cytotoxic agents to directly lyse targeted MDS/AML blasts. Bispecific T-cell engagers (BiTE) and bi- and tri-specific NK cell engagers (BiKE, TriKE) bind and crosslink target antigens to T- and NK effector cells to mediate targeted cell destruction.

As shown in Table 1, a number of CD123-targeting biotherapeutics have entered clinical trials in adult MDS patients over the last 10 years. Flotetuzumab (MGD006) is a bispecific, dual-affinity retargeting (DART) antibody reactive with both CD3 antigen on T-cells and CD123 antigen on AML/MDS cells (Uy et al., 2021b). In a Phase 1 study in therapy-refractory adult AML and high-risk adult MDS patients (NCT02152956), this CD3-engaging bispecific antibody exhibited promising single agent activity with an overall composite response rate of 30\% (Uy et al., 2017). Likewise, APVO436 showed promising single agent activity in high-risk MDS patients (Uckun et al., 2021). Of the $9 \mathrm{R} / \mathrm{R}$ AML/ MDS patients treated at RP2D, 1 AML achieved a prolonged SD with time to progression of 238 days, two AML patients achieved a PR that deepened to a CR with full hematologic recovery, and one MDS patient achieved a marrow CR (Uckun et al., 2021). Among the six evaluable R/R MDS patients, three achieved a marrow $\mathrm{CR}$, and the time to progression ranged from 78 to 321 days (Uckun et al., 2021). This dual-function MDS drug candidate is currently being evaluated in clinical trials for AML and MDS (NCT03647800). Vibecotamab (XmAb14045) is another $\mathrm{CD} 123 \times \mathrm{CD} 3 \mathrm{BiAB}$ that has been evaluated clinically with a $23 \% \mathrm{CR}$ rate in R/R AML patients (Testa et al., 2019). Other CD123 $\times$ CD3 BiAB in early-phase clinical trials in patients with R/R AML include SAR440334 (NCT03594955), a T-cellengaging multispecific monoclonal antibody, and JNJ-63709178 (NCT02715011), a humanized DuoBody.

Like other CD3 engaging $\mathrm{BiAb}, \mathrm{CD} 123 \times \mathrm{CD} 3 \mathrm{BiAB}$ are also associated with cytokine release syndrome (CRS) as a treatmentemergent and potentially life-threatening complication (Uy et al., 
TABLE 1 | Interventional CD123-Targeting biotherapy trials in MDS patients since 2011.

\begin{tabular}{|c|c|c|c|c|c|c|}
\hline $\begin{array}{l}\text { Protocol/ } \\
\text { Trial ID }\end{array}$ & Trial title & $\begin{array}{c}\text { Trial } \\
\text { phase }\end{array}$ & $\begin{array}{c}\text { Primary tested } \\
\text { drug }\end{array}$ & Trial objective & Start date & Supporting URLs \\
\hline NCT04109482 & $\begin{array}{l}\text { A phase I/II, Open Label, } \\
\text { Multicenter Trial to Assess the } \\
\text { Safety and Efficacy of MB-102 in } \\
\text { Patients With Relapsed or } \\
\text { Refractory Blastic Plasmacytoid } \\
\text { Dendritic Cell Neoplasm }\end{array}$ & $|/| \mid$ & $\begin{array}{l}\text { MB-102, } \\
\text { Mustang Bio } \\
\text { CD123 CAR-T }\end{array}$ & $\begin{array}{l}\text { To assess the safety and efficacy of } \\
\text { MB-102 in patients with relapsed or } \\
\text { refractory BPDCN, AML or high- } \\
\text { risk MDS. }\end{array}$ & $\begin{array}{l}\text { February 17, } \\
2020 \text { (Actual) }\end{array}$ & $\begin{array}{l}\text { https://clinicaltrials. } \\
\text { gov/show/ } \\
\text { NCT04109482 }\end{array}$ \\
\hline NCT03594955 & $\begin{array}{l}\text { An Open-label, First-in-human, } \\
\text { Dose Escalation Study of } \\
\text { SAR440234 Administered as } \\
\text { Single Agent by Intravenous } \\
\text { Infusion in Patients With Relapsed } \\
\text { or Refractory Acute Myeloid } \\
\text { Leukemia (R/R AML), B-cell Acute } \\
\text { Lymphoblastic Leukemia (B-ALL), } \\
\text { or High Risk Myelodysplasia } \\
\text { (HR-MDS) }\end{array}$ & $1 / 11$ & $\begin{array}{l}\text { SAR-440234 } \\
\text { CD3 × CD123 BiTE }\end{array}$ & $\begin{array}{l}\text { To determine the maximum tolerated } \\
\text { dose (MTD) of SAR440234 } \\
\text { administered as a single agent in } \\
\text { patients with R/R AML (relapsed or } \\
\text { refractory acute myeloid leukemia), } \\
\text { HR-MDS (high risk myelodysplastic } \\
\text { syndrome), or B-ALL (B-cell acute } \\
\text { lymphoblastic leukemia), and } \\
\text { determine the recommended phase } 2 \\
\text { dose (RP2D) for the subsequent } \\
\text { Expansion part. To assess the activity } \\
\text { of single agent SAR440234 at the } \\
\text { RP2D in patients with R/R AML or } \\
\text { HR-MDS. }\end{array}$ & $\begin{array}{l}\text { October 24, } \\
2018 \text { (Actual) }\end{array}$ & $\begin{array}{l}\text { https://clinicaltrials. } \\
\text { gov/ct2/show/study/ } \\
\text { NCT03594955 }\end{array}$ \\
\hline NCT03647800 & $\begin{array}{l}\text { Phase I/lb Open-Label, Dose- } \\
\text { Escalation Study of APVO436 in } \\
\text { Patients With Relapsed or } \\
\text { Refractory Acute Myeloid Leukemia } \\
\text { (AML) or High-Grade } \\
\text { Myelodysplastic Syndrome (MDS) }\end{array}$ & 1 & $\begin{array}{l}\text { APVO-436 } \\
\text { CD3 × 1CD123 } \\
\text { BiAB }\end{array}$ & $\begin{array}{l}\text { Part 1: To evaluate the safety and } \\
\text { pharmacokinetic profile of APVO436 } \\
\text { to determine a maximum-tolerated } \\
\text { dose and recommended dose for part } \\
\text { 2. Part 2: To assess the clinical activity } \\
\text { and safety profile of APVO436 at the } \\
\text { recommended dose in a larger group } \\
\text { of patients. }\end{array}$ & $\begin{array}{l}\text { December 13, } \\
2018 \text { (Actual) }\end{array}$ & $\begin{array}{l}\text { https://clinicaltrials. } \\
\text { gov/ct2/show/ } \\
\text { NCT03647800 }\end{array}$ \\
\hline NCT03113643 & $\begin{array}{l}\text { Phase } 1 \text { Study of SL-401 in } \\
\text { Combination With Azacitidine or } \\
\text { Azacitidine/Nenetoclax in } \\
\text { Relapsed/Refractory Acute Myeloid } \\
\text { Leukemia (AML) or in Treatment- } \\
\text { Naive Subjects With AML Not } \\
\text { Eligible for Standard Induction } \\
\text { Therapy or in Subjects With High- } \\
\text { Risk Myelodysplastic } \\
\text { Syndrome (MDS) }\end{array}$ & $1 / 11$ & $\begin{array}{l}\text { Tagraxofusp } \\
\text { DT388-IL3, SL- } \\
\text { 401, tagraxofusp- } \\
\text { erzs }\end{array}$ & $\begin{array}{l}\text { To study SL-401 as a possible } \\
\text { treatment for diagnosis of AML and } \\
\text { high-risk MDS. To determine the } \\
\text { safest, highest dose of study drug, SL- } \\
401 \text {, in combination with azacitidine } \\
\text { that can be given to patients with AML } \\
\text { or high-risk MDS. To study the side } \\
\text { effects and best dose of DT(388)IL3 } \\
\text { fusion protein SL- } 401 \text { when given } \\
\text { together with azacitidine in treating } \\
\text { patients with myelodysplastic } \\
\text { syndrome or acute myeloid leukemia } \\
\text { that is untreated, has come back, or } \\
\text { does not respond to treatment. }\end{array}$ & $\begin{array}{l}\text { June 26, } 2017 \\
\text { (Actual) }\end{array}$ & $\begin{array}{l}\text { https://clinicaltrials. } \\
\text { gov/show/ } \\
\text { NCT03113643 }\end{array}$ \\
\hline NCT03011034 & $\begin{array}{l}\text { A phase II Proof-of-Concept Study } \\
\text { to Separately Evaluate the Activity } \\
\text { of Talacotuzumab (JNJ-56022473) } \\
\text { or Daratumumab in Transfusion- } \\
\text { Dependent Subjects With Low or } \\
\text { Intermediate-1 Risk } \\
\text { Myelodysplastic Syndromes (MDS) } \\
\text { Who Are Relapsed or Refractory to } \\
\text { Erythropoiesis-Stimulating Agent } \\
\text { (ESA) Treatment }\end{array}$ & $\|$ & $\begin{array}{l}\text { Daratumumab } \\
\text { Talacotuzumab } \\
\text { Anti-CD123 MoAb }\end{array}$ & $\begin{array}{l}\text { To evaluate the efficacy (transfusion } \\
\text { independence [TI]) of talacotuzumab } \\
\text { (JNJ-56022473) or daratumumab in } \\
\text { transfusion-dependent participants } \\
\text { with low or intermediate-1 risk } \\
\text { Myelodysplastic Syndrome (MDS) } \\
\text { whose disease has relapsed during } \\
\text { treatment with or is refractory to } \\
\text { Erythropoiesis-Stimulating Agent } \\
\text { (ESAs). }\end{array}$ & $\begin{array}{l}\text { February 14, } \\
2017 \text { (Actual) }\end{array}$ & $\begin{array}{l}\text { https://clinicaltrials. } \\
\text { gov/show/ } \\
\text { NCT03011034 }\end{array}$ \\
\hline NCT02992860 & $\begin{array}{l}\text { Single Agent JNJ-56022473 in } \\
\text { MDS and AML Patients Failing } \\
\text { Hypomethylating Agent Based } \\
\text { Therapy }\end{array}$ & $\|$ & $\begin{array}{l}\text { Talacotuzumab } \\
\text { Anti-CD123 MoAb }\end{array}$ & $\begin{array}{l}\text { To evaluate the effect of JNJ- } \\
56022473 \text { in overall hematological } \\
\text { response rate at } 3 \text { months in HMA } \\
\text { refractory/relapsed AML and MDS } \\
\text { patients. }\end{array}$ & $\begin{array}{l}\text { January 7, } \\
2016 \text { (Actual) }\end{array}$ & $\begin{array}{l}\text { https://clinicaltrials. } \\
\text { gov/show/ } \\
\text { NCT02992860 }\end{array}$ \\
\hline
\end{tabular}


TABLE 1 | (Continued) Interventional CD123-Targeting biotherapy trials in MDS patients since 2011.

\begin{tabular}{|c|c|c|c|c|c|c|}
\hline $\begin{array}{l}\text { Protocol/ } \\
\text { Trial ID }\end{array}$ & Trial title & $\begin{array}{c}\text { Trial } \\
\text { phase }\end{array}$ & $\begin{array}{c}\text { Primary tested } \\
\text { drug }\end{array}$ & Trial objective & Start date & Supporting URLs \\
\hline NCT02181699 & $\begin{array}{l}\text { Phase I Study of KHK2823 in } \\
\text { Patients With Acute Myeloid } \\
\text { Leukemia or Myelodysplastic } \\
\text { Syndrome }\end{array}$ & 1 & $\begin{array}{l}\text { KHK-2823 } \\
\text { Anti-CD123 MoAb }\end{array}$ & $\begin{array}{l}\text { To investigate the safety, } \\
\text { pharmacokinetics, immunogenicity } \\
\text { and pharmacodynamics of repeat } \\
\text { doses of KHK2823. }\end{array}$ & $\begin{array}{l}\text { January 6, } \\
2014 \text { (Actual) }\end{array}$ & $\begin{array}{l}\text { https://clinicaltrials. } \\
\text { gov/ct2/show/ } \\
\text { NCT02181699 }\end{array}$ \\
\hline NCT02152956 & $\begin{array}{l}\text { A phase I/II, First in Human, Dose } \\
\text { Escalation Study of MGD006, a } \\
\text { CD123 } \times \text { CD3 Dual Affinity } \\
\text { Retargeting (DART }{ }^{\circledR} \text { ) Bi-Specific } \\
\text { Antibody Based Molecule, in } \\
\text { Patients With Relapsed or } \\
\text { Refractory AML or Intermediate-2/ } \\
\text { High Risk MDS. }\end{array}$ & $1 / 11$ & $\begin{array}{l}\text { Flotetuzumab } \\
\text { CD3 } \times \text { CD123 } \\
\text { DART }\end{array}$ & $\begin{array}{l}\text { To explore the ability of MGD006 to } \\
\text { redirect T cells in relapsed and } \\
\text { refractory acute myeloid leukemia. To } \\
\text { see how the drug acts in the body } \\
\text { (pharmacokinetics, } \\
\text { pharmacodynamics) and to evaluate } \\
\text { potential anti-tumor activity of } \\
\text { Flotetuzumab. }\end{array}$ & $\begin{array}{l}\text { September 6, } \\
2014 \text { (Actual) }\end{array}$ & $\begin{array}{l}\text { https://clinicaltrials. } \\
\text { gov/show/ } \\
\text { NCT02152956 }\end{array}$ \\
\hline
\end{tabular}

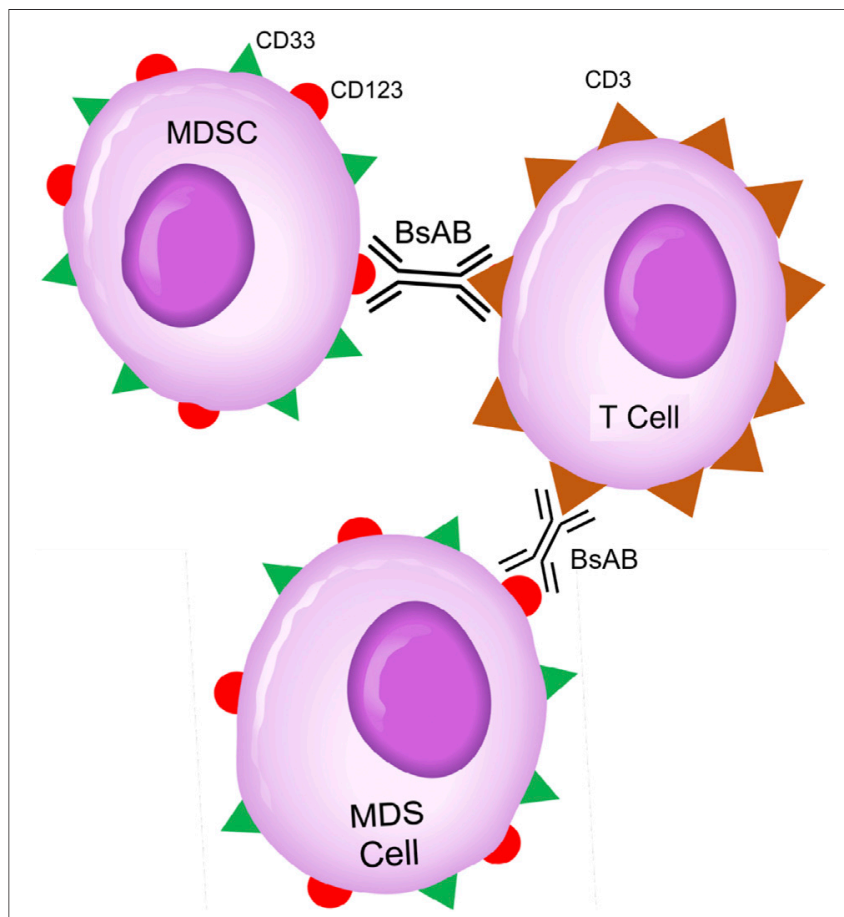

FIGURE 2 | Bispecific CD3 $\times$ CD123 Antibodies Targeting MDS Clones and MDSC Cells in High-Risk MDS Patients. Abbreviations: BsAB: bispecific antibody; MDS: MDS clone; MDSC: Myeloid-derived suppressor cell. See text for a detailed discussion of the rationale of targeting the CD123 and CD33 antigens that are expressed on both MDS clones and MDSCs.

2017; Testa et al., 2019; Uy et al., 2021b; Uckun et al., 2021). CRS was observed in $96 \%$ of AML patients treated with Flotetuzumab (Uy et al., 2017) and 58\% of AML patients treated with Vibecotamab (XmAb14045) (Testa et al., 2019). Within the confines of a small patient and heterogeneous patient population, the CRS rate of $21.7 \%$ in the Phase $1 \mathrm{~B}$ study of APVO436 appeared to compare favorably with the reported CRS rates for the anti-AML bispecific antibodies (Uckun et al., 2021). Intriguingly, none of the 7 MDS patients treated with APVO436 experienced CRS (Uckun et al., 2021). APVO436-related CRS was not required for clinically meaningful responses in $R / R$ AML patients, and it did not affect their survival outcome. Prolonged stabilization of disease, partial remissions and complete remissions were achieved in both patients who experienced CRS as well as patients who did not experience CRS after APVO436 infusions (Uckun et al., 2021). The predominant proinflammatory cytokine in CRS events associated with $\mathrm{CD} 123 \mathrm{xCD} 3 \mathrm{BiAB}$ appears to be interleukin 6 (IL-6) and therefore tocilizumab at standard doses combined with dexamethasone. is commonly used to manage this potential complication (Testa et al., 2019; Uckun et al., 2021).

\section{DISCUSSION}

CD123-targeting, CD3-engaging BiAB bring cytotoxic T-cells (CTLs) within close vicinity of target $\mathrm{CD} 123^{+}$cells to create "cytolytic synapses" as a short bridge between MDS cells and CTLs, triggering CTL activation and destruction of targeted MDS cells (Figure 2). APVO436 is a recombinant T-cell engaging humanized $\mathrm{BiAB}$ designed to redirect host $\mathrm{T}$-cell cytotoxicity in an MHC-independent manner to CD123-expressing blast cells from patients with hematologic malignancies (Comeau et al., 2019; Uy et al., 2021b; Uy et al., 2017; Uckun et al., 2021) (Figure 2). APVO436 was generally well tolerated in adults with relapsed AML and high-risk MDS with manageable toxicity and a promising benefit to risk profile (Uckun et al., 2021). APVO436 at the recommended Phase 2 dose (RP2D) level also produced early evidence of clinical efficacy. Both prolonged SD and CRs were observed as early evidence of clinical efficacy in R/R AML patients. Further, of the 6 MDS patients evaluable for response, three achieved a marrow CR (Uckun et al., 2021).

T-cells in the immunosuppressive BMME of AML and highrisk MDS patients with markedly deregulated innate and adaptive immune responses are characterized by a phenotype of "exhaustion" with augmented expression of PD-1, T cell immunoglobulin and ITIM domain (TIGIT), and T-cell immunoglobulin and mucin-domain containing-3 (TIM-3) antigens as well as functional cytotoxic T-cell (CTL) deficiency (Brauneck et al., 2021; Goswami et al., 2016; Ladikou et al., 2020; Jia et al., 2018). Furthermore, MDS patients treated with HMAs were reported to have increased PD-1 expression on peripheral 
blood mononuclear cells (Yang et al., 2014). The proof-ofconcept that the CD3-engaging bispecific antibody APVO436 can sufficiently enhance the cytotoxicity of the dysfunctional and exhausted T-cells in relapsed AML patients and induce CRs in $\mathrm{R} / \mathrm{R}$ AML patients and marrow CRs in MDS demonstrates its clinical impact potential for the treatment of CD123-expressing hematologic malignancies. The combination of APVO436 with immune-checkpoint inhibitors and/or CAR-T/CAR-NK cells may result in greater anti-leukemic activity, but the safety and tolerability of such combination immunotherapy awaits clinical confirmation.

We hypothesize that the addition of CD $3 \times$ CD123 BiABs will eradicate residual $\mathrm{CD}_{12} 3^{+}$MDS clones as well as leukemic stem cells. Notably, Venetoclax has recently been shown to augment $\mathrm{T}$-cell effector function by increasing the production of reactive oxygen species and Azacitidine has been shown to enhance sensitivity of AML cells to cytotoxic T-cells by activating the STING pathway (Lee et al., 2021). These observations provide a compelling rationale for combining BiABs such as Flotetuzumab and APVO436 with Venetoclax, Azacitidine, or both to treat newly diagnosed high-risk MDS patients. Recently, Ganesan et al. reported a new and promising CD123 targeting BiAB platform aimed at selective recruitment of $\mathrm{V} \gamma 9^{+} \gamma \delta$ T cells as an alternative to $\mathrm{CD} 3$-engaging anti-CD123 BiABs which warrants clinical evaluation (Ganesan et al., 2021). In addition to CD123 targeting biotherapeutic agents, CD33 targeting antibodies and BiABs $(\mathrm{CD} 3 \times \mathrm{CD} 33$ or $\mathrm{CD} 16 \times \mathrm{CD} 33)$ also show potential for the treatment of high-risk MDS patients because of the high level expression on both MDS clones and MDSC (Eksioglu et al., 2017); (Gleason et al., 2014). The early stage trials listed in Table 1 have not been designed to specifically address the potential of reducing the size of the MDSC population in the bone marrow microenvironment of the adult MDS patient population. We recommend that hypothesis-generating or hypothesis-testing biomarker studies become an integral part of the clinical studies in the future to fully assess the clinical potential of CD123targeting $\mathrm{BiAB}$.

CD123 expression has not been extensively studied in pediatric MDS, including juvenile myelomonocytic leukemia (JMML) (Niemeyer et al., 2019). Louka et al. recently reported that the $\mathrm{CD}_{3} 8^{+}$myeloid progenitor compartment in JMML

\section{REFERENCES}

Al Hussaini, M. H., Ritchey, J., Rettig, M. P., Eissenberg, L., Uy, G. L., Chichili, G., et al. (2013). Targeting CD123 in Leukemic Stem Cells Using Dual Affinity Retargeting Molecules (Darts ${ }^{\circledR}$ ). Blood 122, 360. doi:10.1182/ blood.v122.21.360.360

Aldoss, I., Uy, G. L., Vey, N., Emadi, A., Sayre, P. H., Walter, R. B., et al. (2020). Flotetuzumab as Salvage Therapy for Primary Induction Failure and Early Relapse Acute Myeloid Leukemia. Blood 136, 16-18. doi:10.1182/blood-2020134576

Bai, C., Rui, L., Laleau, R., Liu, F., Ab, O., Setiady, Y., et al. (2020). The BiTE (Bispecific T-Cell Engager) Platform: Development and Future Potential of a Targeted Immuno-Oncology Therapy across Tumor Types. Cancer 126, 3192-3201. doi:10.1002/cncr.32909

Brauneck, F., Haag, F., Woost, R., Wildner, N., Tolosa, E., Rissiek, A., et al. (2021). Increased Frequency of TIGIT+CD73-CD8+ T Cells with a TOX+ TCF-1low patients, including both common myeloid progenitor cells and granulocyte monocyte progenitors express CD123 (Louka et al., 2021). Therefore, it is possible that targeting CD123 may also have clinical potential in treatment of some pediatric patients with $\mathrm{CD} 123^{+}$MDS.

\section{CONCLUSION}

Recombinant $\mathrm{T}$-cell engaging humanized bispecific antibodies can be designed to redirect host T-cell cytotoxicity in an MHCindependent manner and in a target-dependent manner, selectively, to CD123-expressing blast cells in patients with hematologic malignancies.

They have clinical impact potential in high-risk MDS as it may both prevent disease progression/immune evasion by reducing the numbers of CD123 ${ }^{+}$MDSC (Edwards et al., 2010; Gustafson et al., 2015; Uhel et al., 2019; Dysthe and Parihar, 2020; Khan et al., 2020; Domagala et al., 2021) and delay the development of secondary AML by T-cell mediated destruction of $\mathrm{CD} 123^{+} \mathrm{CD} 34^{+}$ blast cells.

\section{AUTHOR CONTRIBUTIONS}

Each author (FU and JW) has made significant and substantive contributions to the study, reviewed and revised the manuscript, provided final approval for submission of the final version. FU conceived the review, analyzed the contents of relevant publications, and wrote the original draft of the article. No medical writer or editor was involved.

\section{FUNDING}

The authors declare that this study received funding from Aptevo Therapeutics. F.M.U. is a consultant for Aptevo Therapeutics. The funder was not involved in the study design, collection, analysis, interpretation of data, the writing of this article or the decision to submit it for publication. All authors declare no other competing interests.

Profile in Patients with Newly Diagnosed and Relapsed AML. Oncoimmunology 10 (1), 1930391. doi:10.1080/2162402X.2021.1930391

Chen, J., Kao, Y.-R., Sun, D., Todorova, T. I., Reynolds, D., Narayanagari, S.-R., et al. (2019). Myelodysplastic Syndrome Progression to Acute Myeloid Leukemia at the Stem Cell Level. Nat. Med. 25 (1), 103-110. doi:10.1038/s41591-018-0267-4

Chen, X., Eksioglu, E. A., Zhou, J., Zhang, L., Djeu, J., Fortenbery, N., et al. (2013). Induction of Myelodysplasia by Myeloid-Derived Suppressor Cells. J. Clin. Invest. 123 (11), 4595-4611. doi:10.1172/JCI67580

Comeau, M. R., Gottschalk, R., Daugherty, M., Sewell, T., Sewell, T., Misher, L., Bannink, J., Johnson, S., Parr, L., Kumer, J., Jablonski, D., DeFrancesco, M., Bienvenue, D., Hoyos, G. H., McMahan, C. J., and Gross, J. A. (2019). “APVO436, a Bispecific Anti-cd123 X Anti-CD3 ADAPTIR ${ }^{\mathrm{TM}}$ Molecule for Redirected T-Cell Cytotoxicity with Limited Cytokine Release, Is Well Tolerated in Repeat Dose Toxicology Studies in Cynomolgus Macaques," in Proceedings of the American Association for Cancer Research Annual Meeting 2019, Atlanta, GAPhiladelphia (PA), 2019 Mar 29-Apr 3 (AACR; Cancer Res). Abstract nr LB-199 [abstract]. 
Daver, N., Alotaibi, A. S., Bücklein, V., and Subklewe, M. (2021). T-Cell-Based Immunotherapy of Acute Myeloid Leukemia: Current Concepts and Future Developments. Leukemia 35 (7), 1843-1863. doi:10.1038/s41375-021-01253-x

Domagala, M., Laplagne, C., Leveque, E., Laurent, C., Fournié, J.-J., Espinosa, E., et al. (2021). Cancer Cells Resistance Shaping by Tumor Infiltrating Myeloid Cells. Cancers 13 (2), 165. doi:10.3390/cancers 13020165

Dysthe, M., and Parihar, R. (2020). Myeloid-Derived Suppressor Cells in the Tumor Microenvironment. Adv. Exp. Med. Biol. 1224, 117-140. doi:10.1007/ 978-3-030-35723-8_8

Edwards, J. V., Zhang, H., and Mackall, C. L. (2010). "Abstract 3818: CD11c+CD123+ Human Myeloid Dendritic Cells Generated Using IL4, IL13 and IL3 Show Characteristics of Myeloid Derived Suppressor Cells," in Proceedings of the 101st Annual Meeting of the American Association for Cancer Research, Washington, DCPhiladelphia (PA), Apr 17-212010 (AACR; Cancer Res). doi:10.1158/1538-7445.AM10-3818

Eksioglu, E. A., Chen, X., Heider, K.-H., Rueter, B., McGraw, K. L., Basiorka, A. A., et al. (2017). Novel Therapeutic Approach to Improve Hematopoiesis in Low Risk MDS by Targeting MDSCs with the Fc-Engineered CD33 Antibody BI 836858. Leukemia 31 (10), 2172-2180. doi:10.1038/ leu. 2017.21

Gañán-Gómez, I., Wei, Y., Starczynowski, D. T., Colla, S., Yang, H., Cabrero-Calvo, M., et al. (2015). Deregulation of Innate Immune and Inflammatory Signaling in Myelodysplastic Syndromes. Leukemia 29, 1458-1469. doi:10.1038/ leu.2015.69

Ganesan, R., Chennupati, V., Ramachandran, B., Hansen, M. R., Singh, S., and Grewal, I. S. (2021). Selective Recruitment of $\gamma \delta$ T Cells by a Bispecific Antibody for the Treatment of Acute Myeloid Leukemia. Leukemia 35, 2274-2284. doi:10.1038/s41375-021-01122-7

Garcia-Manero, G. (2014). Myelodysplastic Syndromes: 2014 Update on Diagnosis, Risk-Stratification, and Management. Am. J. Hematol. 89, 97-108. doi:10.1002/ajh.23642

Gleason, M. K., Ross, J. A., Warlick, E. D., Lund, T. C., Verneris, M. R., Wiernik, A., et al. (2014). CD16xCD33 Bispecific Killer Cell Engager (BiKE) Activates NK Cells against Primary MDS and MDSC CD33+ Targets. Blood 123, 3016-3026. doi:10.1182/blood-2013-10-533398

Goswami, M., Oetjen, K., Mulé, B. M. P., Sheela, M. S., Wong, H. Y., Liu, Q., et al. (2016). Increased Frequencies of PD-1+ CD8+ Marrow-Infiltrating Lymphocytes Associated with Highly Clonal T-Lymphocyte Expansions in Relapsed and Refractory AML Patients but Not Healthy Adults. Blood 128, 1644. doi:10.1182/blood.V128.22.1644.1644

Götze, K. S., and Platzbecker, U. (2018). Old Dogs, New Tricks: Revisiting Immune Modulatory Approaches for Myelodysplastic Syndromes. Hemasphere 2, e162. doi:10.1097/HS9.0000000000000162

Gustafson, M. P., Lin, Y., Maas, M. L., Van Keulen, V. P., Johnston, P. B., Peikert, T., et al. (2015). A Method for Identification and Analysis of Non-overlapping Myeloid Immunophenotypes in Humans. PLoS One 10 (3), e0121546. doi:10.1371/journal.pone.0121546

Hwang, K., Park, C.-J., Jang, S., Chi, H.-S., Kim, D.-Y., Lee, J.-H., et al. (2012). Flow Cytometric Quantification and Immunophenotyping of Leukemic Stem Cells in Acute Myeloid Leukemia. Ann. Hematol. 91 (10), 1541-1546. doi:10.1007/ s00277-012-1501-7

Isidori, A., Cerchione, C., Daver, N., DiNardo, C., Garcia-Manero, G., Konopleva, M., et al. (2021). Immunotherapy in Acute Myeloid Leukemia: Where We Stand. Front. Oncol. 11, 656218. doi:10.3389/fonc.2021.656218

Jia, B., Wang, L., Claxton, D. F., Ehmann, W. C., Rybka, W. B., Mineishi, S., et al. (2018). Bone Marrow CD8 T Cells Express High Frequency of PD-1 and Exhibit Reduced Anti-leukemia Response in Newly Diagnosed AML Patients. Blood Cancer J. 8, 34. doi:10.1038/s41408-018-0069-4

Jin, L., Lee, E. M., Ramshaw, H. S., Busfield, S. J., Peoppl, A. G., Wilkinson, L., et al. (2009). Monoclonal Antibody-Mediated Targeting of CD123, IL-3 Receptor a Chain, Eliminates Human Acute Myeloid Leukemic Stem Cells. Cell Stem Cell 5 (1), 31-42. doi:10.1016/j.stem.2009.04.018

Jordan, C. T., Upchurch, D., Szilvassy, S., Guzman, M., Howard, D., Pettigrew, A., et al. (2000). The Interleukin-3 Receptor Alpha Chain Is a Unique Marker for Human Acute Myelogenous Leukemia Stem Cells. Leukemia 14 (10), 1777-1784. doi:10.1038/sj.leu.2401903

Khan, A. N. H., Emmons, T. R., Wong, J. T., Alqassim, E., Singel, K. L., Mark, J., et al. (2020). Quantification of Early-Stage Myeloid-Derived Suppressor Cells in
Cancer Requires Excluding Basophils. Cancer Immunol. Res. 8 (6), 819-828. doi:10.1158/2326-6066.CIR-19-0556

Kovtun, Y., Jones, G. E., Adams, S., Harvey, L., Audette, C. A., Wilhelm, A., et al. (2018). A CD123-Targeting Antibody-Drug Conjugate, IMGN632, Designed to Eradicate AML while Sparing normal Bone Marrow Cells. Blood Adv. 2, 848-858. doi:10.1182/bloodadvances.2018017517

Ladikou, E. E., Sivaloganathan, H., Pepper, A., and Chevassut, T. (2020). Acute Myeloid Leukaemia in its Niche: The Bone Marrow Microenvironment in Acute Myeloid Leukaemia. Curr. Oncol. Rep. 22, 27. doi:10.1007/s11912-0200885-0

Lee, J., Khan, D. H., Hurren, R., Xu, M., Na, Y., Kang, H., et al. (2021). Venetoclax Enhances $\mathrm{T}$ Cell-Mediated Anti-Leukemic Activity by Increasing ROS Production. Blood 138 (3), 234-245. doi:10.1182/blood.2020009081

Li, L. J., Tao, J. L., Fu, R., Wang, H. Q., Jiang, H. J., Yue, L. Z., et al. (2014). Increased CD34+CD38-CD123+ Cells in Myelodysplastic Syndrome Displaying Malignant Features Similar to Those in AML. Int. J. Hematol. 100 (1), 60-69. doi:10.1007/s12185-014-1590-2

Louka, E., Povinelli, B., Rodriguez-Meira, A., Buck, G., Wen, W. X., Wang, G., et al. (2021). Heterogeneous Disease-Propagating Stem Cells in Juvenile Myelomonocytic Leukemia. J. Exp. Med. 218 (2), e20180853. doi:10.1084/ jem. 20180853

Marvel, D., and Gabrilovich, D. I. (2015). Myeloid-Derived Suppressor Cells in the Tumor Microenvironment: Expect the Unexpected. J. Clin. Invest. 125 (9), 3356-3364. doi:10.1172/JCI80005

Movahedi, K., Guilliams, M., Van den Bossche, J., Van den Bergh, R., Gysemans, C., Beschin, A., et al. (2008). Identification of Discrete Tumor-Induced Myeloid-Derived Suppressor Cell Subpopulations with Distinct T CellSuppressive Activity. Blood 111 (8), 4233-4244. doi:10.1182/blood-2007-07099226

National Cancer Institute (2016). Browse the SEER Cancer Statistics Review 19752016. Available at: https://seer.cancer.gov/csr/1975_2016/browse_csr.php? sectionSEL=13\&pageSEL=sect_13_table.16\#table6 (Accessed September 20, 2021).

National Cancer Institute (2021). Myelodysplastic Syndromes Treatment $\left(\mathrm{PDQ}^{\circledR}\right)$-health Professional Version. Available at: https://www.cancer.gov/ types/myeloproliferative/hp/myelodysplastic-treatment-pdq (Accessed March 22, 2021).

Niemeyer, C. M. (2019). "Pediatric MDS Including Refractory Cytopenia and Juvenile Myelomonocytic Leukemia," in The EBMT Handbook: Hematopoietic Stem Cell Transplantation and Cellular Therapies [Internet]. Editors E Carreras, C Dufour, M Mohty, and N Kröger. 7th ed. (Cham (CH): Springer). Chapter 74. doi:10.1007/978-3-030-02278-5_74

Parker, K. H., Beury, D. W., and Ostrand-Rosenberg, S. (2015). Myeloid-Derived Suppressor Cells. Adv. Cancer Res. 128, 95-139. doi:10.1016/ bs.acr.2015.04.002

Platzbecker, U., Kubasch, A. S., Homer-Bouthiette, C., and Prebet, T. (2021) Current Challenges and Unmet Medical Needs in Myelodysplastic Syndromes. Leukemia 35, 2182-2198. doi:10.1038/s41375-021-01265-7

Sallman, D. A., and List, A. (2019). The central Role of Inflammatory Signaling in the Pathogenesis of Myelodysplastic Syndromes. Blood 133, 1039-1048. doi:10.1182/blood-2018-10-844654

Sekeres, M. A., Watts, J., Radinoff, A., Sangerman, M. A., Cerrano, M., Lopez, P. F., et al. (2021). Randomized Phase 2 Trial of Pevonedistat Plus Azacitidine versus Azacitidine for Higher-Risk MDS/CMML or LowBlast AML. Leukemia 35 (7), 2119-2124. doi:10.1038/s41375-02101125-4

Syed, K., Naguib, S., Liu, Z.-J., Cimmino, L., and Yang, F.-C. (2020). Novel Combinations to Improve Hematopoiesis in Myelodysplastic Syndrome. Stem Cel Res Ther 11 (1), 132. doi:10.1186/s13287-020-01647-1

Tabata, R., Chi, S., Yuda, J., and Minami, Y. (2021). Emerging Immunotherapy for Acute Myeloid Leukemia. Int. J. Mol. Sci. 22 (4), 1944. doi:10.3390/ ijms 22041944

Testa, U., Pelosi, E., and Castelli, G. (2019). CD123 as a Therapeutic Target in the Treatment of Hematological Malignancies. Cancers 11 (9), 1358. doi:10.3390/ cancers 11091358

Testa, U., Pelosi, E., and Frankel, A. (2014). CD 123 Is a Membrane Biomarker and a Therapeutic Target in Hematologic Malignancies. Biomark Res. 2 (1), 4. doi:10.1186/2050-7771-2-4 
Testa, U., Riccioni, R., Militi, S., Coccia, E., Stellacci, E., Samoggia, P., et al. (2002). Elevated Expression of IL-3Ra in Acute Myelogenous Leukemia Is Associated with Enhanced Blast Proliferation, Increased Cellularity, and Poor Prognosis. Blood 100 (8), 2980-2988. doi:10.1182/blood-2002-03-0852

Uckun, F. M., Lin, T. L., Mims, A., Patel, P., Lee, C., Shahidzadeh, A., et al. (2021). A Clinical Phase 1B Study of the CD3xCD123 Bispecific Antibody APVO436 in Patients with Relapsed/Refractory Acute Myeloid Leukemia or Myelodysplasia. Cancers 13, 4113. . in press. doi:10.3390/cancers 13164113

Uhel, F., Azzaoui, I., Le Gallou, S., Fest, T., Tarte, K., and Roussel, M. (2019). EarlyStage Myeloid-Derived Suppressor Cell Count: Basophil Exclusion Matters. J. Allergy Clin. Immunol. 144 (4), 1125-1127. doi:10.1016/j.jaci.2019.06.027

Uy, G. L., Aldoss, I., Foster, M. C., Sayre, P. H., Wieduwilt, M. J., Advani, A. S., et al. (2021). Flotetuzumab as Salvage Immunotherapy for Refractory Acute Myeloid Leukemia. Blood 137 (6), 751-762. doi:10.1182/blood.2020007732

Uy, G. L., Aldoss, I., Foster, M. C., Sayre, P. H., Wieduwilt, M. J., Advani, A. S., et al. (2021). Flotetuzumab as Salvage Immunotherapy for Refractory Acute Myeloid Leukemia. Blood 137 (6), 751-762. doi:10.1182/blood.2020007732

Uy, G. L., Godwin, J., Rettig, M. P., Vey, N., Foster, M., Arellano, M. L., et al. (2017). Preliminary Results of a Phase 1 Study of Flotetuzumab, a CD123 X CD3 Bispecific Dart Protein, in Patients with Relapsed/Refractory Acute Myeloid Leukemia and Myelodysplastic Syndrome. Blood 130, 637. doi:10.1182/blood.v130.suppl_1.637.637

Vergez, F., Green, A. S., Tamburini, J., Sarry, J.-E., Gaillard, B., Cornillet-Lefebvre, P., et al. (2011). High levels of CD34+CD38low/-CD123+ blasts are predictive of an adverse outcome in acute myeloid leukemia: a Groupe Ouest-Est des Leucemies Aigues et Maladies du Sang (GOELAMS) study. Haematologica 96 (12), 1792-1798. doi:10.3324/haematol.2011.047894

Yang, H., Bueso-Ramos, C., Dinardo, C. D., Estecio, M. R., Davanlou, M., Geng, Q.-R., et al. (2014). Expression of PD-L1, PD-L2, PD-1 and CTLA4 in Myelodysplastic Syndromes Is Enhanced by Treatment with
Hypomethylating Agents. Leukemia 28, 1280-1288. doi:10.1038/ leu. 2013.355

Younos, I. H., Abe, F., and Talmadge, J. E. (2015). Myeloid-derived Suppressor Cells: Their Role in the Pathophysiology of Hematologic Malignancies and Potential as Therapeutic Targets. Leuk. Lymphoma 56 (8), 2251-2263. doi:10.3109/10428194.2014.987141

Zhan, D., and Park, C. Y. (2021). Stem Cells in the Myelodysplastic Syndromes. Front. Aging 2, 719010. doi:10.3389/fragi.2021.719010

Conflict of Interest: Author FU was employed by Ares Pharmaceuticals, LLC and was a consultant for Aptevo Therapeutics and for Reven Pharmaceuticals. These financial relationships could be construed as a potential conflict of interest.

The remaining author declares that the research was conducted in the absence of any commercial or financial relationships that could be construed as a potential conflict of interest.

Publisher's Note: All claims expressed in this article are solely those of the authors and do not necessarily represent those of their affiliated organizations, or those of the publisher, the editors, and the reviewers. Any product that may be evaluated in this article, or claim that may be made by its manufacturer, is not guaranteed or endorsed by the publisher.

Copyright (c) 2021 Uckun and Watts. This is an open-access article distributed under the terms of the Creative Commons Attribution License (CC BY). The use, distribution or reproduction in other forums is permitted, provided the original author(s) and the copyright owner(s) are credited and that the original publication in this journal is cited, in accordance with accepted academic practice. No use, distribution or reproduction is permitted which does not comply with these terms. 